Ballas, D. and Dorling, D. (2017) Chapter 10: Spatial Divisions of Poverty and Wealth, in D. DeBats, I. Gregory and D. Lafreniere (Eds) The Routlege Companion to Spatial History, Abingdon, Routledge, pp.204-222. - Final manuscript as submitted, not the actual printed and proof-read chapter.

\title{
Spatial Divisions of Poverty and Wealth
}

\author{
Dimitris Ballas and Danny Dorling
}

Dimitris Ballas is Professor of Economic Geography at the University of Groningen, The Netherlands. He was formerly Associate Professor in the Department of Geography at the University of the Aegean and a Senior Lecturer in the Department of Geography at the University of Sheffield. He has also held Visiting Research Scholar positions at Harvard University and at the International Institute for Applied Systems Analysis (Austria) and a Visiting Professor position at Ritsumeikan University (Japan). He has published widely in the fields of social and spatial inequalities, regional science and Geoinformatics in the Social Sciences.

Danny Dorling is the Halford Mackinder Professor of Geography at the University of Oxford. He grew up in Oxford and went to University in Newcastle upon Tyne. He has worked in Newcastle, Bristol, Leeds, Sheffield and New Zealand. Much of his work is available open access (see www.dannydorling.org). With a group of colleagues he helped create the website www.worldmapper.org which shows who has most and least in the world. His work concerns issues of housing, health, employment, education, wealth and poverty.

\section{Acknowledgements}

This chapter is an abridged and updated version of Dorling, D. and Ballas, D. (2008) Chapter 6: Spatial Divisions of Poverty and Wealth, in T. Ridge and S. Wright (Eds) Understanding Poverty, Wealth and Inequality: Policies and Prospects, Bristol: Policy Press. (pp.103-134). We are grateful to our colleagues Jan Rigby, Ben Wheeler, Bethan Thomas, Eldin Fahmy, Dave Gordon and Ruth Lupton, Anna Barford, Mark Newman and John Pritchard who worked with us on projects upon which this chapter draws. We are also grateful to Ailsa Allen for redrawing and producing Figures 3 and 4 in a suitable format for this book. 


\begin{abstract}
This chapter concerns very recent history and a time when the UK government was an all UK government and had enough funds to support academic work in the social sciences. Part of the GIS research reported here was funded by (what was then called) the Office of the Deputy Prime Minister and conducted by the Social and Spatial Inequalities group, University of Sheffield (of which we were both members). Another part of the work discussed here was a project on poverty and wealth funded by the Joseph Rowntree Foundation during those same New Labour years and we are grateful to our colleagues Jan Rigby, Ben Wheeler, Bethan Thomas, Eldin Fahmy, Dave Gordon and Ruth Lupton who worked on the Rowntree report. This chapter also considers the early use of GIS in research on world inequalities and draws on work with colleagues in the United States (Mark Newman) and Anna Barford (now at Cambridge). An archive of this work can be found at www.worldmapper,org a project that was initially funded by the Leverhulme Trust.
\end{abstract}

\title{
Introduction
}

In this chapter we describe how GIS has been used in recent years to understand why, locally, nationally in Britain and worldwide, the bulk of the population seems destined to live in "underperforming" regions; as they do so, more are poor, and the rich are becoming ever more separate from the rest. This chapter traces changes over time: decades, centuries and in one case millennia; all involve inequality, poverty and wealth.

Poverty and wealth are not two sides of the same coin. Many people are neither poor nor wealthy. There are thus more sides than two options in how we are divided by our access to resources (income) and the uses to which we put those resources (expenditure). The very poorest are poor no matter how counted: they have low income, wealth, inadequate possessions and know they are poor and are unambiguously known as poor by others. With colleagues we have termed this group 'Core Poor' in Britain ${ }^{1}$. 
In the United States the concept of core poor equates best to the eighth of the population living below the nation's miserly official poverty line. Worldwide the concept equates best to the measure of those living on a couple of dollars a day. The Core Poor in Britain, and those beneath the line in the United States, and those on less than $\$ 2$ a day in the poor world only just survive. Even attempts at enumerating absolute measures of poverty have to be relative to be meaningful across all of the world, even at the same point in time. Quantifying the very richest is more difficult. To a man (it is usually still a man) with access to $\$ 1$ billion, a man with only $\$ 1$ million appears a pauper. In between the extremes of core-poverty and unimaginable riches runs the gamut of inequity along which most of us are strung.

Being poor or wealthy are, however, qualitatively different experiences from being a little bit better or worse off along a continuum. Both involve social exclusion from the norms of society. Furthermore, neither could exist without the other, but they are better described as very different sized facets on a many sided die rather than opposite side of the coin.

This chapter shows some examples of how GIS has been used to explore the geography of people living at, and between, these extremes. To do this in we start with a city, then move out to the country and end with the world.

\section{Manchester: so much to answer for}

We start the analysis at the city level, focusing on Manchester, the first city in the world to be industrialized. It was the first city in which mass human labour was put to work in a way that so thoroughly de-humanized people. "Manchester so much to answer for" were originally the lyrics to a popular song that very few of its younger listeners realize concerned the killers of children known as the "Moors Murderers" ${ }^{2}$. But, as the song implies, Manchester - or rather the way of 
treating human beings first seen in Manchester - has much more to answer for than that.

The University of Manchester has the date of its founding now inscribed in the logo of the new unified mega-university: "Manchester 1824". This is roughly a well-lived lifetime (75 years) older than other provincial English cities. It is not by chance that the city boasts of being something special. Take a trip to the Manchester Museum of Science and Industry and one walks into a giant warehouse established as a wharehouse just a decade after the University. A couple of decades later and Friedrich Engel's 'Conditions of the working Class' was published ${ }^{3}$. In the 1850s, the expectation of life's length from birth in Manchester was just 32 years, falling to 31 years in the $1860 \mathrm{~s}^{4}$. In the central district of that city it was as low as 29 by then, exceeded - as worse - only by an all- time life-expectancy low of 25 years in those same years in nearby Liverpool ${ }^{5}$. Human life has rarely been valued lower outside of times of war, genocide or in the worse of famines.

The urban experience of systemic poverty that can be wrought through capitalism began in Manchester. By the turn of twentieth century standards of living in North West England were little better than during the middle of the nineteenth. In fact the long hot summer of 1904 saw infants die in Manchester close to the rates ( 1 in 4 before their first birthday) that they still die in the poorest places on earth a century later. And it was in Manchester that it was first realized that those deaths were not an act of God, but due to the squalor that accompanies poverty - squalor that was quantified in the numbers of flies living around new-born infants:

"By means of a number of beer-traps Dr Niven contrived to count the flies in some dozen houses in Manchester during the summer months of 1904, and from these data he concluded that the advent of the house-fly in numbers precedes by a short time the increase in the number of deaths from diarrhoea. In the fortnight ending August 13th, for instance, the number of flies caught in these traps was 37,521 , the maximum in any fortnight, and in the fortnight following the maximum number of deaths from diarrhoea occurred - namely, 192. " 6

In the century that followed the long hot summer of 1904, life in Manchester changed for most, almost beyond recognition. Nevertheless, the City of Manchester is still the district of England with the lowest male life expectancy from birth, despite its center now containing one of the most dynamic business districts in the country. The city also now again contains some extremely 
affluent enclaves, including high rise luxurious apartment blocks with penthouses that cost a fortune.

The current local authority district of the city of Manchester stretches long and thin from north to south and so it is possible to chart a route - a journey - that covers most of it and does not look too contrived. Journeys have long been a way in which geographical inequalities in Britain were studied.

A journey through Manchester and out into leafy Macclesfield district is described in Figure 1, which is shown on a map with areas shaded according to the average incomes of those who live there. Average incomes in the center of the city were less than half the average in the rural hinterland of Manchester. Many of those (who can) tended to get out but still usually drive in for work. These are just the inequalities between averages, not extremes, and between a measure already greatly redistributed before it is counted (it is income plus entitlements rather than earned income alone that is shown)...The methodology used to draw Figure 1 involved the division of Manchester and its neighbouring district of Macclesfield up into a series of areas for which averages could be calculated. More information on the data and methods can be found in a detailed technical report to the UK Office for the Deputy Prime Minister ${ }^{7}$.

It should be noted that if we had shown inequalities in wealth, rather than income, along this journey the differences would be manifoldly far higher. Had we taken a related measure, but of something very rare - the murder rate, the differences would not be possible to calculate as in places within the city the rate is amongst the highest in England whereas it is practically zero in parts of the outskirts. It is not just in the United States that such extremes occur. Almost all else in life changes along with the trend in inequalities in incomes along this journey through Manchester.

The average incomes shown in Figure 1 were estimates which were produced by the UK Office for National Statistics. They almost certainly underestimate the extent of income inequalities along the route, as they are the products of a statistical model based on relatively limited information. 
For instance, one of the variables upon these income estimates are based is the proportion of households in each geographical area which are classified as "professionals and intermediate", masking the considerable income variation within this group.

Figure 1:

1998 Neighbourhoods Weekly Income

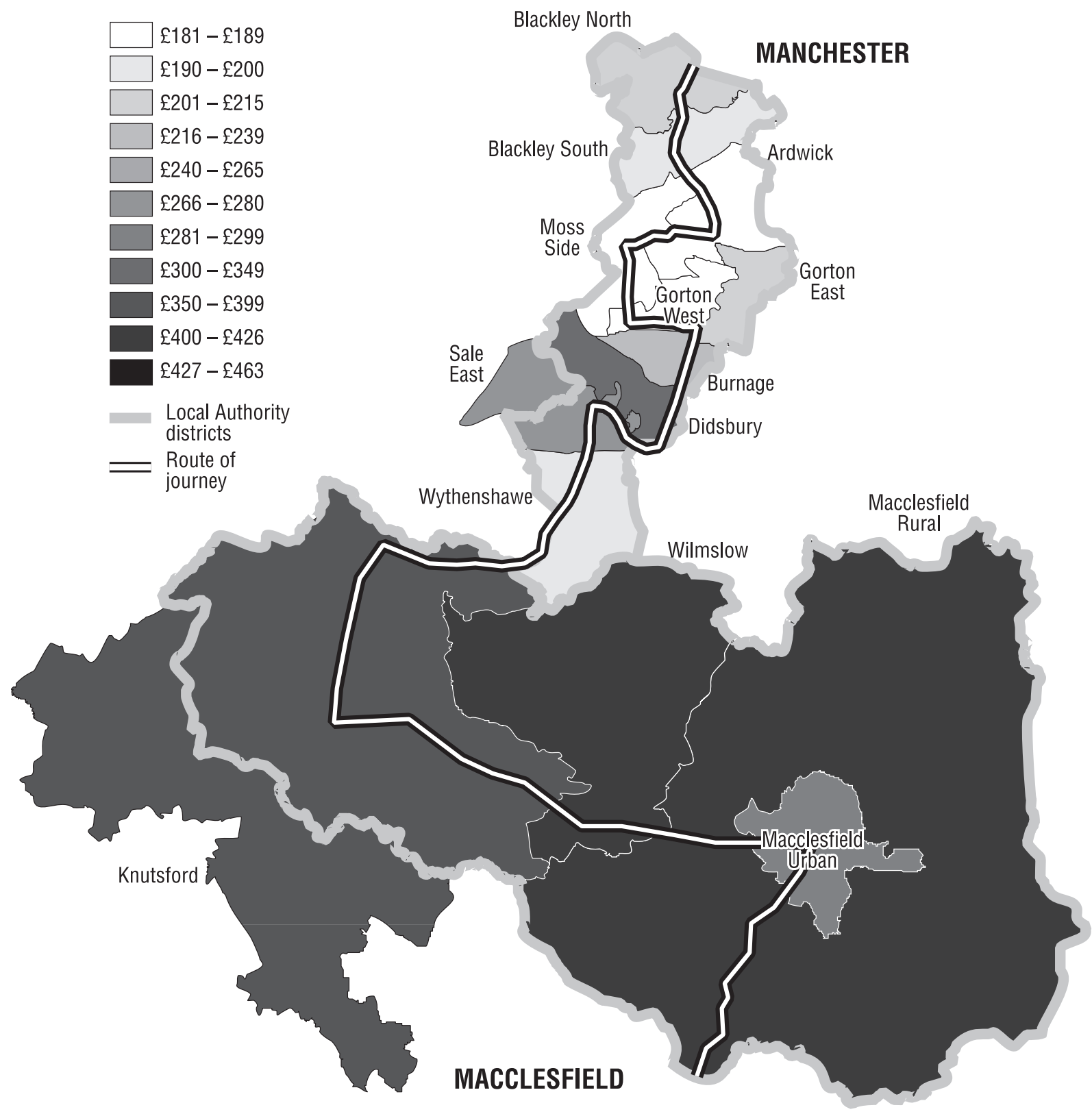


From the above discussion it becomes obvious that in order to properly analyze socio-economic inequalities and their spatial manifestations it is necessary to have good quality small area data on income and wealth. Despite strong arguments of the utility of measures of income in small areas, the UK government has been avoiding the inclusion of such a question in Census questionnaires, on the grounds that it could negatively affect the response rates, as a lot of the respondents would object to being asked this question or find it hard to complete. However, it should be noted that almost all government social surveys, as opposed to the Census, in Britain ask this question and it is also successfully asked in other national censuses. A further argument against the inclusion of an income question in the Census is that it could breach confidentiality rules by making it possible to identify individual respondents. Yet, it should be noted that individual's answers to census questions, unlike other government surveys, are confidential and cannot be released from ONS for 100 years under the census legislation ${ }^{8}$.

Given the lack of good quality geographical income data that would allow a thorough investigation of the spatial distribution of poverty and wealth, there have been considerable efforts within the social sciences to estimate income (rather than wealth) for geographical areas that are smaller than the levels at which published data exist ${ }^{9}$.

Similar issues arise when analyzing social and spatial inequalities in wealth, as this is also something not asked in the census. Social scientists deal with this lack of wealth data by combining information from a wide range of sources including the Census of population (number of households and socio-economic characteristics), Building Societies and Land Registry (house price data). A recent study in Britain published for Shelter, the housing charity, used such methods, revealing the emergence of an unprecedented housing wealth gap ${ }^{10}$. More recent studies ${ }^{11} 12$ extended such methodologies and estimated and visualized the size and geographical distribution of household wealth. 
Just as it is possible to produce a profile of the changing income distribution along a journey once area data has been estimated, so too can many other aspects of life related to poverty and wealth be measured and visualized. Figure 2 shows three different transects from north Manchester through to the rural southern hinterland as illustrations of this possibility.

\section{FIGURE 2a}

Mean detached house price in £s ('000s) 2001: Blakely North to Macclesfield Rural

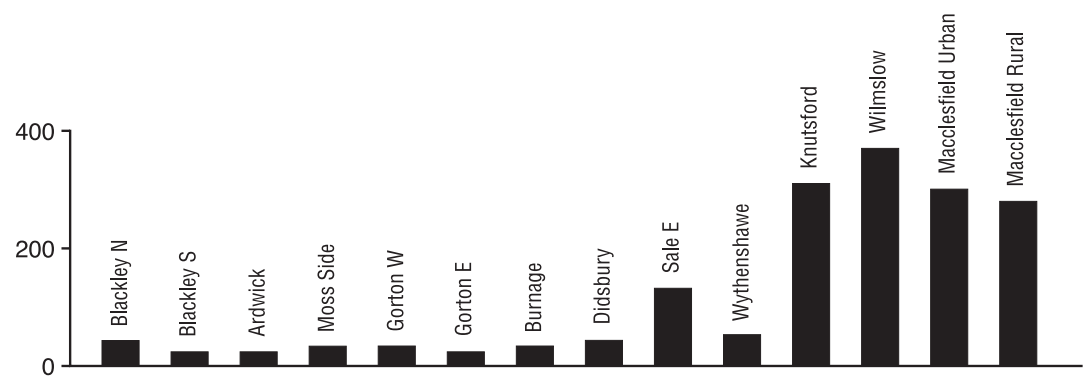

\section{FIGURE 2b}

Mean detached house price in £s 1995-2003: Blakely North to Macclesfield Rural

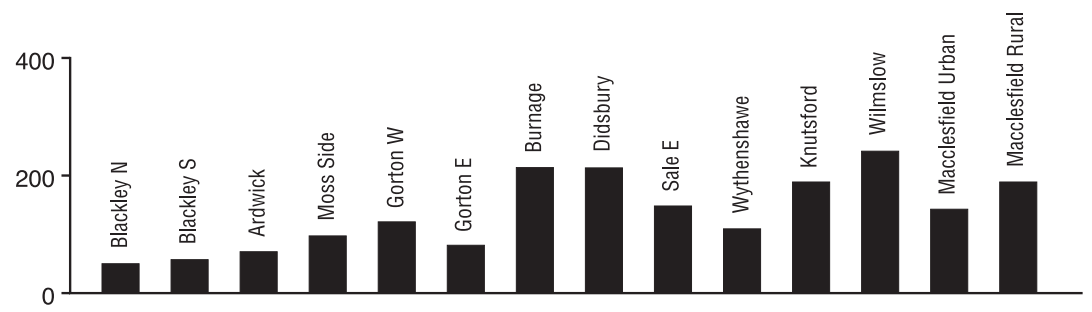

FIGURE 2c

Change in \% of population born in Republic of Ireland :1991-2001 Blakely North to Macclesfield Rural

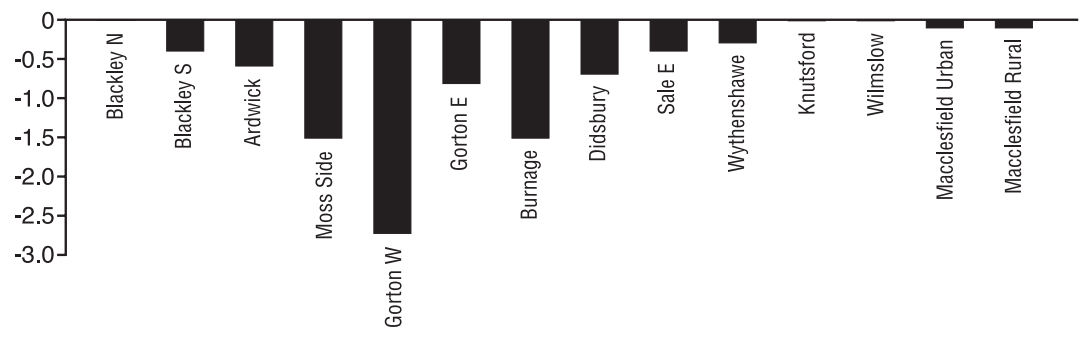


Firstly figure 2a shows how detached property (free standing residential dwelling) is much more highly valued in the suburbs and rural parts of the route. Figure $2 b$ shows that this type of property increased in estimated value much more in recent years as compared to that in the city center. Figure $2 \mathrm{c}$ shows how the decline in a particular migrant group - those born in Ireland occurs in rough tandem with these trends in income and wealth distributions and redistributions and how the socio-economic status and power of residential population may affect the price of property. The center of Manchester is an area that has been typified by immigration since the first industrial buildings were raised. Figure $2 c$ shows the decline of the Irish born due to death in old age and out-migration: it charts the decline of a group which came in large numbers both in the 1840 s and 1960s (and often in between) - but no longer.

Manchester was the first modern example of how income, poverty, wealth and inequality tends to be distributed around a city when much of the market in housing, transportation and wages is mostly unregulated. 


\section{Spatial Divisions in Britain}

The journey into Manchester and out into rural Macclesfield is a journey between extremes, although it is one of very many possible such journeys and is certainly not the most extreme that could be taken: Figures 3 and 4 show that journey drawn with three small arrows upon two maps of all of Britain. These are population cartogram maps and each hexagon is a parliamentary constituency.

Population cartograms differ from conventional maps of places which show areas as they might appear from space, ignoring population distribution. Looking at a country or a city without regard to population distorts economic and social geography. Population cartograms show each area of the country drawn roughly in proportion to the size of its population and thus representing the area in social and economic terms as it would be represented politically: they give the people a "fairer" representation $^{131415} 16$.

Here we use such cartograms to study the economic geography of Britain and in particular the geographical distribution of people that can be described as "core poor" and "exclusive wealthy" according to a study of poverty and wealth that was originally funded and published by the Joseph Rowntree Foundation ${ }^{17}$ (also see discussion below). In this section we draw on this work and also highlight the areas that we discussed above to the discussion of the previous section by highlighting the geography of poverty and wealth in the areas covered by the journey from Manchester to leafy Macclesfield that we described above (see annotated arrow in Figures 3 and 4). In particular, the first of those maps (Figure 3) shows the proportion of the population that makes up the "core poor" in each small part of the country and the second map (Figure 4) shows how many of those in each place were "exclusive wealthy" by the year 2000. If we consider the journey we described in the previous section, we can observe that this passes through some of the areas containing the highest proportions of "core poor" folk - and then into places that contain some of the highest proportions of exclusively wealth households living in the north of England. However, as Figure 4 shows, the British "exclusive wealthy" almost exclusively live in a ring of areas to the west of London in the south of England. 
Figure 3: The geography to where the poorest of the poor lived in Britain in 2000.

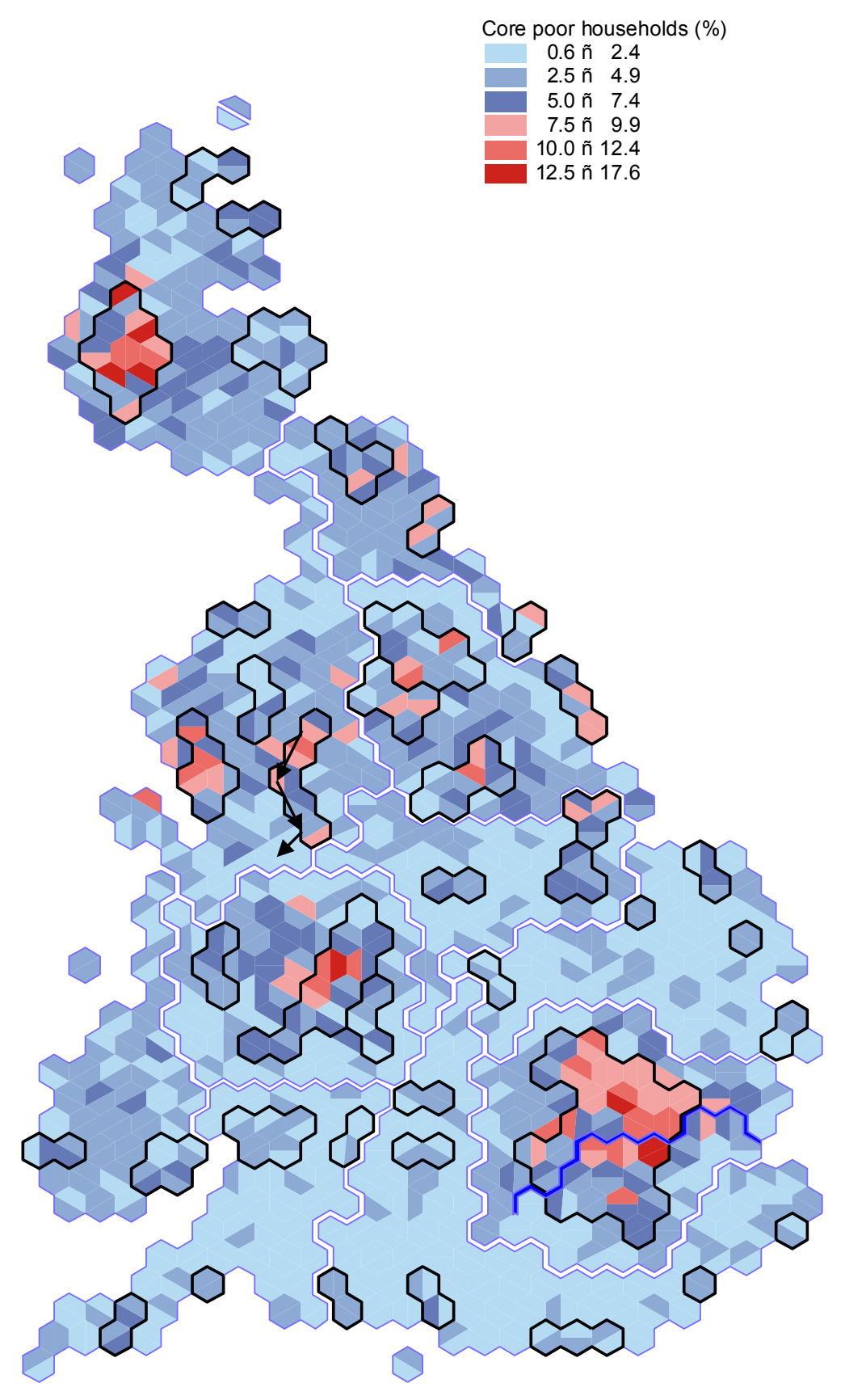

Source: Thomas, B, Dorling, D (2007), Identity in Britain: A cradle-to-grave atlas, Policy Press, Bristol: p. 290. 
Figure 4: The geography to where the exclusively wealthy lived most in Britain in 2000

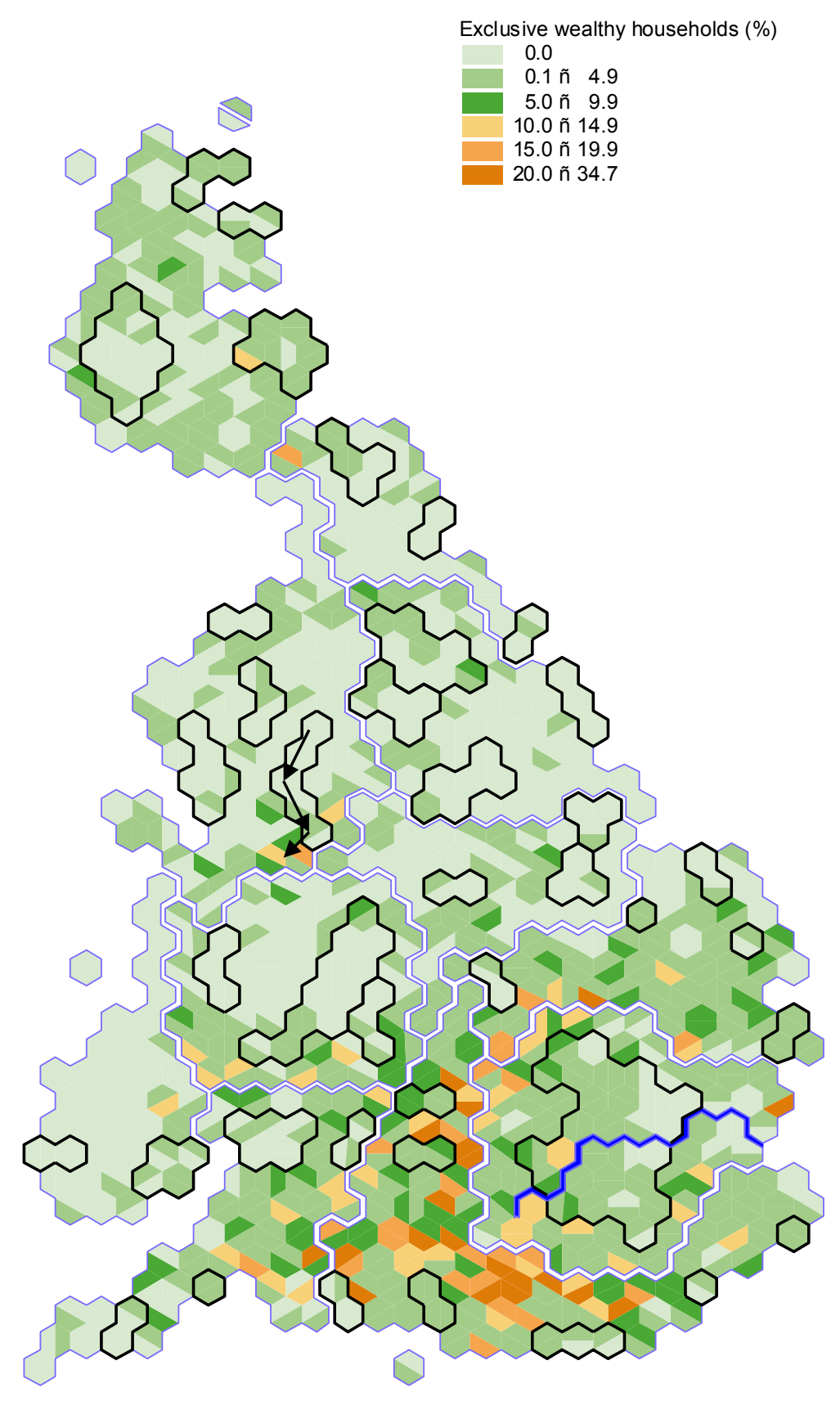

Source: Thomas, B, Dorling, D (2007), Identity in Britain: A cradle-to-grave atlas, Policy Press, Bristol: p. 290. 
Research into the extent and trends in poverty in Britain has generally failed to produce measures for relatively small areas that can be compared over time. To overcome this problem we extended the so called and well-established "Breadline Britain" methodology which takes into account the public's perception and the extent to which households have access to what are considered to be publicly perceived necessities ${ }^{18}$ to produce estimates for small areas across the country around the time of the $1971,1981,1991$ and 2001 censuses of population ${ }^{19}$. Because we mix this data with that from surveys usually taken a few years earlier $(1968,1983,1990$ and 1999) we will use the dates $1970,1980,1990$ and 2000 to describe these points in time for which we have estimated measures of poverty and wealth. We also use information of housing prices and consumption by affluent individuals to produce estimates for the same areas of the numbers of households that were asset- wealthy and exclusively wealthy.

Our definition of exclusive wealth is the theoretical opposite of what is normally seen in defining poverty as relative deprivation. Peter Townsend's standard definition of poverty is that the poor lack the opportunities to enjoy a standard of living commensurate with societal norms, and are thus deprived from participating as full citizens of their society ${ }^{20}$. Exclusive wealth in contrast confers privilege through being able to secure benefits by dint of wealth not generally available to the public at large (and certainly not to the poor).

The 'exclusive wealthy' can thus be defined as those living above a high wealth line. This has to be a line sufficiently high that people, living above it, are able to exclude themselves from participating in the norms of society (if they so wish), moving "as far from the life of the average citizen as the addict in a blanket under Waterloo Bridge" and no longer inhabiting "the same planet as the rest of us, hermetically sealed in smoke-windowed limo, private jet, private island, private everything"21. 
Expenditure Survey (FES) in combination with the Households Below Average Income (HBAl) adjustments to the incomes of the very 'rich'22. The HBAI adjustments account for household size and type when considering household disposable (i.e. after tax and including welfare payments) income, and are the same as those used in the Breadline Britain methodology ${ }^{23}$. The adjusted FES data was then used to define the average level of income at which the following exclusive activities tend to occur, such as children going to independent schools, the use of private health care, second home ownership, having a boats and paying for private club membership fees. To estimate the geographical distribution of exclusively wealthy households, housing data were used to estimate the equivalent asset wealth accompanying this exclusive behaviour.

The group that is the mirror image of the exclusively wealthy in theoretical terms is living below the relative poverty line: the breadline poor. However, at any one time, just as for every person who is rich there is a subset who are extremely rich; for all who experience poverty, there is a subset who are extremely poor. The group termed the core-poor here are those who are suffering from a combination of all of normative, felt, and comparative poverty. That is, they are people who are simultaneously income poor (normative), subjectively poor (felt) and necessities/deprivation poor (comparatively poor): they are a subset of those who are comparatively poor but do not necessarily fell poor or are normatively poor: the breadline poor. Finally there are those who are neither poor nor wealthy. Table 1 shows the proportion of households in Britain we estimate to be in each group at the start of each decade from 1970 to 2000. 
Table 1: Poverty and wealth measures for Great Britain, 1970 to 2000.

\begin{tabular}{cccccc}
\hline Year & \% core poor* & $\begin{array}{c}\text { \% breadline } \\
\text { poor }\end{array}$ & $\begin{array}{c}\text { \% non-poor, } \\
\text { non-wealthy }\end{array}$ & $\begin{array}{c}\text { \% asset } \\
\text { wealthy }\end{array}$ & $\begin{array}{c}\text { \% exclusive } \\
\text { wealthy* }\end{array}$ \\
\cline { 1 - 1 } 1970 & 14.4 & 23.1 & $n / a^{* *}$ & n/a** & 7.4 \\
1980 & 9.8 & 17.1 & 66.1 & 16.8 & 6.9 \\
1990 & 14.3 & 21.3 & 55.7 & 23.0 & 3.5 \\
2000 & 11.2 & 27.0 & 50.4 & 22.6 & 5.6 \\
\hline
\end{tabular}

* Note that 'core poor' and 'exclusive wealthy' are subsets of 'breadline poor' and 'asset wealthy' respectively); see main report for estimates of variability around the exclusive wealth estimates.

${ }^{* *}$ Housing wealth data were unavailable for 1970 ; since asset wealth could not be calculated, neither could the proportion of non-poor, non-wealthy at this time.

Source: Dorling, D., Rigby, J., Wheeler, B., Ballas, D., Thomas, B., Fahmy, E., Gordon, D. and Lupton, R. (2007) Poverty, wealth and place in Britain, 1968 to 2005, Policy Press, Bristol (free pdf copies available from: http://www.jrf.org.uk/bookshop/eBooks/2019-poverty-wealth-place.pdf)

Table 1 shows that we estimate that only half of all households are neither poor nor wealthy $(50.4 \%)$ - however two thirds are generally included in the norms of society. That two thirds is the non-poor non-wealthy plus the asset wealthy less the exclusive wealth $(50.4+22.6-5.6=67.4 \%)$. Note that the middle three columns of Table 1 sum to one hundred and that the proportion who are excluded from the norms of society either by dint of their breadline poverty or their exclusive wealth can be calculated by summing the second and fifth column of data in the table. Over thirty years the socially excluded (rich and poor) have grown from $30.5 \%(23.1 \%+7.4 \%)$ to $32.6 \%(27.0 \%+5.6 \%)$. The extremes were were only a quarter of households in 1980 (when the poor were at a minima) and 1990 (when recession in the southern part of England decreased t the wealth of the rich). 
Note also that we have no estimate of the asset wealthy in 1970 and so can derive no estimate of those households that are non-poor and non-wealth in that year also. Finally it should be noted that there were fewer core-poor in 2000 as compared to 1990 - almost certainly due to social innovations such as the introduction of a minimum wage and tax credits for families in lower paid work. However, it should also be noted that the definition of "core poor" used here is perhaps excessively strict.

It could well be argued that a robust definition of poverty would be anyone who satisfied any two of the following three conditions: 1) they think they are poor; 2) they have a low income; 3 ) they have low wealth. The low wealth criteria might be that they are among the "breadline poor", or simply that they have almost no savings.

The precise definitions of poverty lines become less important when two out of three criteria are used. Most folk understand that someone is poor if they have low income and low wealth - whether they think of themselves as poor or not. Most people are happy that someone with savings who does not think of themselves as poor is not poor, even if they have a low income - and so on. This two out of three criteria rule was originally proposed by Bradshaw and Finch ${ }^{24}$. We do not use it further here but it is well worth considering for future use - and for measuring much more than poverty. The same principle would apply to the definition of the rich, e.g. that they satisfy any two of the following: thinking they are rich, having a high income; and/or having high wealth.

Having determined the national proportions of households that can be categorized as asset wealthy, exclusive wealthy, breadline poor and core poor, or none of the above, we next need to show the spatial distribution of poverty and wealth. 
The index of dissimilarity is the minimum proportion of households that would have to move between areas if each area were to have an even proportion of households of a given type. Table 2 gives the result of applying this statistical test and shows that by the year 2000 , a majority (59.7\%) of the exclusive wealthy would have had to move out of their neighborhood to somewhere less exclusive were they to no longer be so extremely clustered (as shown in Figure 4). That proportion is much as it was in 1990, but much higher than it was in 1980.

Table 2. The Index of Dissimilarity for each of the five measures

\begin{tabular}{lcrrr}
\hline & $\mathbf{1 9 7 0}$ & $\mathbf{1 9 8 0}$ & $\mathbf{1 9 9 0}$ & $\mathbf{2 0 0 0}$ \\
\hline Core Poor & $12.3 \%$ & $15.6 \%$ & $15.3 \%$ & $14.1 \%$ \\
\hline Breadline Poor & $14.7 \%$ & $16.7 \%$ & $17.1 \%$ & $18.3 \%$ \\
\hline Non-poor, non-wealthy & $*$ & $15.4 \%$ & $16.7 \%$ & $19.8 \%$ \\
\hline Asset Wealthy & ${ }^{*}$ & $34.9 \%$ & $34.5 \%$ & $40.1 \%$ \\
\hline Exclusive Wealthy & ${ }^{*}$ & $43.6 \%$ & $60.6 \%$ & $59.7 \%$ \\
\hline
\end{tabular}

*Small-area estimates of asset and exclusive wealthy households were not available for 1970, meaning that non-poor, non-wealthy households could also not be estimated at this time.

Of all the five groups shown in Table 2 only the core-poor are slightly less spatially concentrated by the year 2000 as compared to 1990 . Every other group has become more spatially concentrated. Using the breadline measure from the time it was first deployed, we can say that those living beneath the breadline have never been as physically separated from the rest of society by their geography as they presently are. Similarly those who are 'normal' were by the year 2000 less likely to be mixing with folk who were either poor or wealthy. Finally, the asset wealthy are now more spatially segregated in Britain than they were in either 1980 or 1990.

The extent of these spatial divides change slowly. However, those divides are deep and in general they are deepening in England. What then of the rest of the world? 


\section{Economic Spatial Divisions Worldwide}

So far in this chapter, we have considered the spatial distribution of poverty and wealth at the local and then the national scale, showing that there have been significant increases in social and spatial inequalities within and between areas at all these levels. In countries like Britain, both poor and wealthy households have become more and more geographically segregated from the rest of society over the last three decades.

Now we turn our attention to the spatial manifestation of poverty and wealth at the global scale and we critically discuss the ways in which global institutions such as the World Bank, meant to deal with global poverty, approach these issues.

Similar trends of geographical polarization such as those described at the national and local level above are observed at the global scale but it is important to remember that when discussing global poverty and wealth we should bear in mind that different societies have different concepts of wealth. What people want and what people need changes over time and that the concept of poverty constantly evolves and therefore, as noted earlier, the subsistence approach to the definition of poverty is inadequate.

"By necessities, I understand not only the commodities which are indispensably necessary for the support of life, but whatever the customs of the country renders it indecent for creditable people, even of the lower order, to be without. A creditable day labourer would be ashamed to appear in public without a linen shirt."25

As the commodities that countries use to define what a person to be creditable are constantly changing, ${ }^{7}$ it can be argued that it is respect that matters most in people's lives and that nations provide respect through the equitable access to resources we allow each other - through to income and wealth. Some truths appear harder to grasp 
than others. In Britain economists have known for over two centuries that a shoe is not merely an aid for walking to work as they have known in social policy for over one hundred years that a postage stamp is not just a necessity for paying bills ${ }^{26}{ }^{27}$. Adam Smith in the eighteenth century and Seebohm Rowntree at the end of the nineteenth explained how a little luxury is also a necessity of life. However, in the pits of the more dismal side of the science of economics this has yet to be grasped.

We can see this in the World Bank myths that nearly everything that matters is improving ${ }^{28}$. We end this chapter questioning those myths. By defining "nearly everything that matters" as what is taken absolutely for granted in the rich world (or "donor countries" in World Bank speak), Charles Kenney suggests that living standards worldwide are converging $^{29}$ and societal inequalities are decreasing. There are many simple mistakes in this work and they stem from s the error in Kenney's (and by implication the World Bank's) central tenet which is summarized as follows ${ }^{30}$ : if people in the poorest countries of the world begin to receive a little more of what the richest came to expect to receive generations earlier, then the world is becoming fairer. Or, in other words - if more of the world's poor can now afford a cheap pair of shoes (rather than no shoes) and live on an amount closer to 2 dollars a day rather than 1 dollar - then the world has become a fairer place. This ignores the growing incomes of the rich in the richest countries or the number and types of shoes worn there, or the fact that people no longer need to walk miles to get water in the rich world.

In his conclusion, Kenney implies that "donor nations" should not be concerned that they may be impoverishing poor nations through debt repayments because the world is set to get fairer anyway. 
Figure 5a - Change in the Human Development Index 'to achieve' 1975-2005

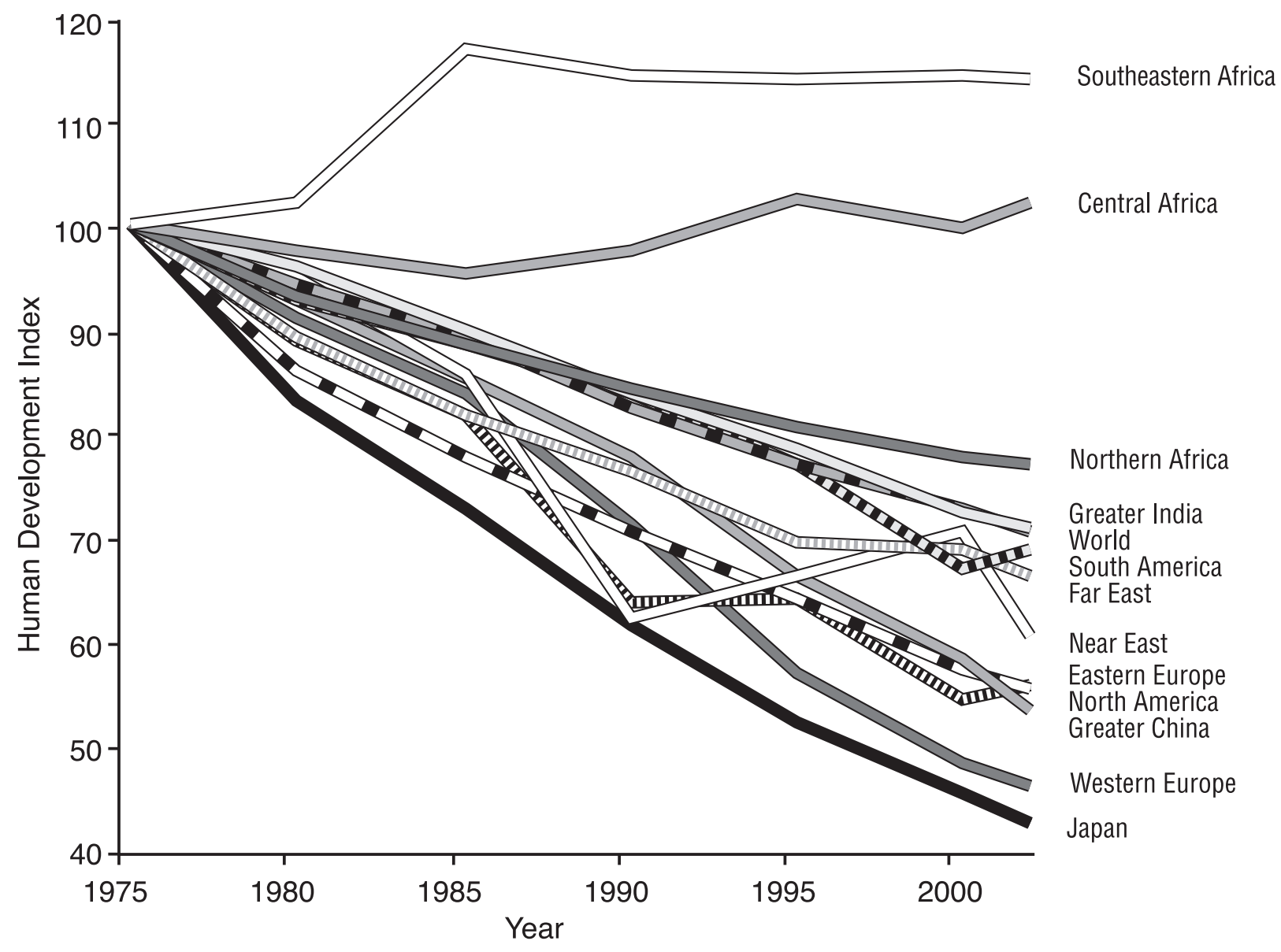

Nevertheless, Figure 5a uses the same data as Kenney, and shows a somewhat different global trend. More specifically it shows the gap between full human development as defined by the United Nations Development Programme (UNDP) and the lack of progress since 1975. Figure 5a also shows how close to achieving a simple measure of the achievement of full human development each of 12 regions of the world since 1975.

The extremes are defined by Japan and Africa. In Japan the majority of improvement towards UNDP 'utopia' has achieved in the last twenty-five years. Utopia here is defined as living to the age of 85 , being educated to tertiary level and having an average income of $\$ 40,000$. Japan also has the most equitable income distribution of the twelve regions 
and it is often argued that it has a cohesive society ${ }^{31}$. In contrast most of Africa is further from that utopia than it was in 1975. On average central and south-eastern Africa's combined life expectancy, educational enrolment and incomes are worse now in absolute terms than they were in 1975.

In between these extremes the remainder of the world forms a diverging continuum. In general those who had most to begin with have gained most and those which had least have the furthest to go (and further now to go than they had in 1975).China has achieved a tiny fraction more since 1975 than North America but other than that not only has there been overall divergence worldwide (in everything that matters most: health, wealth and learning). The richer a set of countries were to begin with the better they have done.

Once countries are grouped as in Figure 5a there are no exceptions. In figure $5 a$ the twelve regions are comparable. In other words - even if you run things as well as China has done - or as badly as North America has done - you, as a world region, can hardly alter your end position that is determined by where you started in the "development race". The extent of such divergence is also mirrored in the global distribution of income as seen in Figure $5 \mathrm{~b}$ that presents the estimated World Income by region, based on income estimates by Angus Maddison who developed a time series of historical statistics for the World Economy over the last 800 years $^{32}$. 
Figure 5b: Change in average incomes over time $1200-2000$ compared to world average

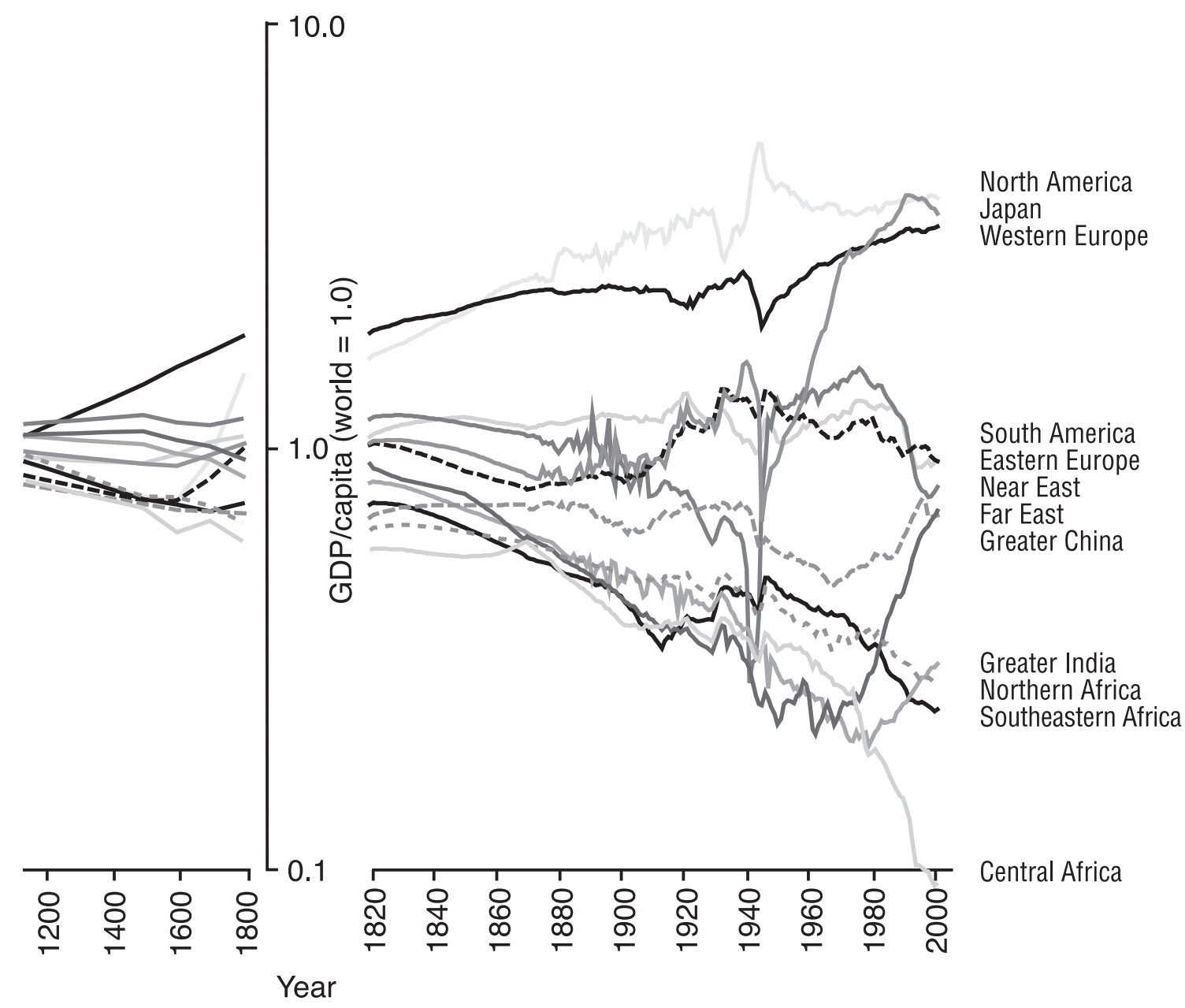

It is in the short term interest of the bankers of the richest people in the richest (donor) nations to present a picture of world living standards converging, of a race where those who began miles behind the leaders are beginning to catch up. A fictional nanny gave good advice on the motivation of banking over four decades ago:

"They must feel the thrill of totting up a balanced

book A thousand ciphers neatly in a row

When gazing at a graph that shows the profits

up Their little cup of joy should overflow! $!^{33}$ 
Another way of demonstrating how unequal the world has become is to redraw the map of the world in proportion to the distribution of poverty and wealth. Figure 6a shows a world map where area is drawn in proportion to income of less than one US dollar a day. As can be seen, the areas of countries in Africa and Asia are by far the largest, whereas, it is very difficult to distinguish the shapes of countries in Europe and North America. Similarly, Figure 6b shows a world map where area is drawn in proportion to over $\$ 200$ a day. In contrast to Figure 6a, European and North American countries dominate this map, whereas the areas of Asian and African countries have shrunk. It is interesting to note that the world has become so unequal that the rich folk of Macclesfield described earlier (see Figure 1) which a century ago was a remote rural settlement are now part of the map of world wealth - and can be identified on a world map where area is drawn in proportion to who has an income of over $\$ 200$ a day! (see Figure $6 b$ )

\section{Conclusion}

There are leaps of imagination required to see the true extent of the spatial divisions of population and wealth in the world. Here we have tried to show how these can range from a journey across the city of Manchester to a journey across Britain on a map stretched and squeezed so that both poor and rich are equally visible to a map of the world as defined by average incomes received in each state.

Locally within Manchester, nationally across Britain, and worldwide the spatial divisions of poverty and wealth are deepening. Locally, this is normally hardest to see and occurs more slowly. At times the trends are reversed. Nationally it is more obvious, especially in countries like Britain where a "pear-shaped" picture of economic development is emerging $^{34}$, where the bulk of the population were destined to live in an underperforming bulge of regions from which the 'productive' winners are moving further away. Worldwide 
the spatial divisions of poverty and wealth have never been as deep and inequalities across the planet are accelerating.

The geography of poverty that we illustrated in Figure 3 has continued to deepen and now there is absolute immiseration. Real incomes have fallen and for the first time since the 1930s. Modern day soup kitchens have opened. Now they are called food banks and very large numbers of people in the poorest parts of the country are being fed for several days a year through such charity. At the very same time the geography of wealth that we showed in Figure 4 has also deepened. There has been a boom in housing prices in just those areas shown to have already been most wealthy in the year 2000. Those who own property in the South East are, and feel, much richer again. Those who have to rent often now spend the majority of their income on rent.

A comparable set of statistics to those shown in table 1 has not yet been created, but when it is, it will show both core and breadline poverty and exclusive wealth to have risen. Preliminary results of more recent work were indicating this to be especially acute in London $^{35}$.

On the other hand, some of the worldwide gaps illustrated in Figure 5 ('a' and 'b') may finally be narrowing. Since the 2008 economic crash economic growth has been slowest in some of the richest parts of the world (North America and Europe) and greatest in Africa and Asia - but from a very low base in Africa's case.

Nevertheless the richest $1 \%$ of people in the world continue to become much richer and are expected to hold the majority of the wealth in the world by the end of the year $2016^{36}$. Locally, nationally and globally, for most people in the world, spatial divisions of poverty and wealth continue to widen. The US president, the Pope, the head of the IMF, and the president of China all lamented these developments very recently. However, $\mathrm{t}$ is not impossible that we are near a turning point. As Christmas 2016 approaches there are the beginnings of signs suggesting the wealthy might soon not be so wealthy, but as yet it is too early to tell. 
Figure 6a: The world drawn in proportion to those living on $\$ 1$ a day or less. Source:

Worldmapper map 179 (www.worldmapper.org)

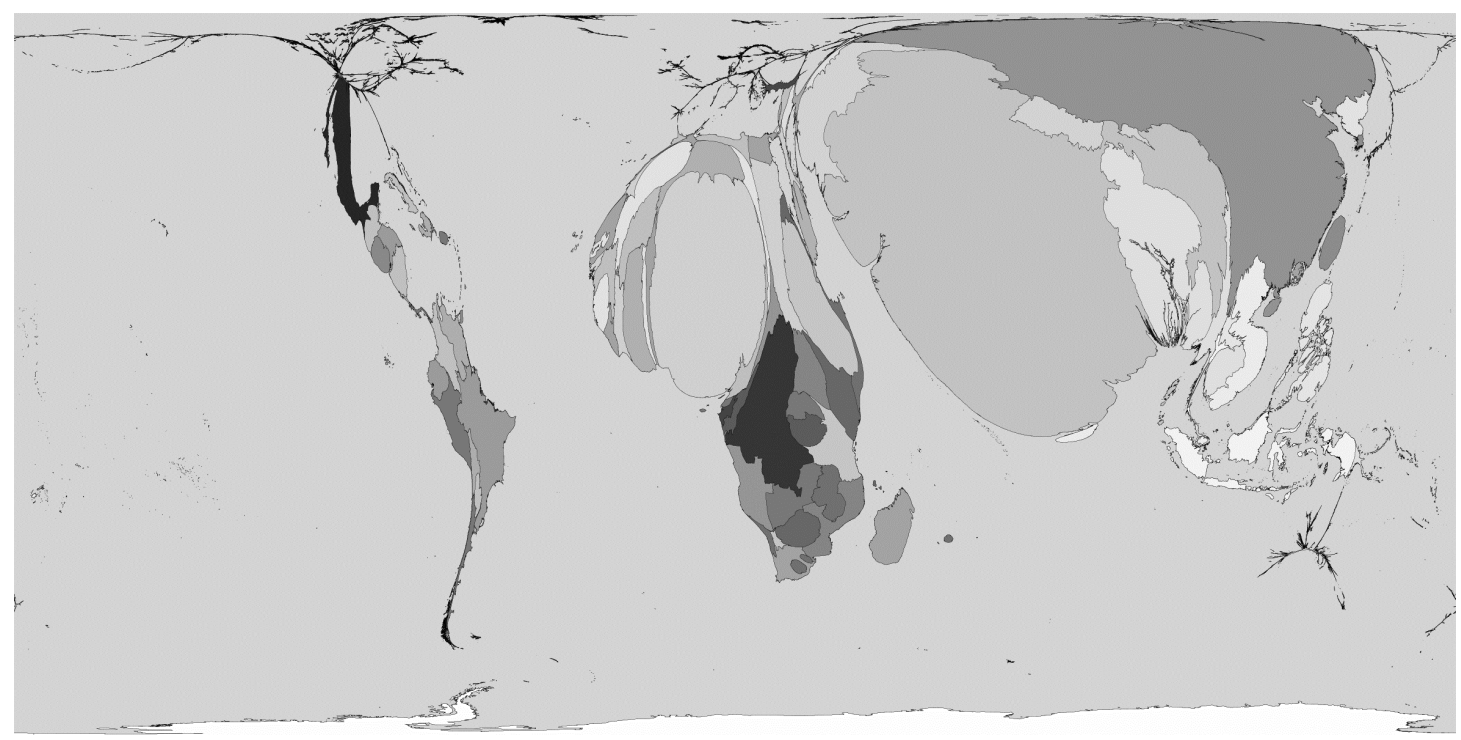

Figure 6b: The world drawn in proportion to those living on $\$ 200$ a day or more

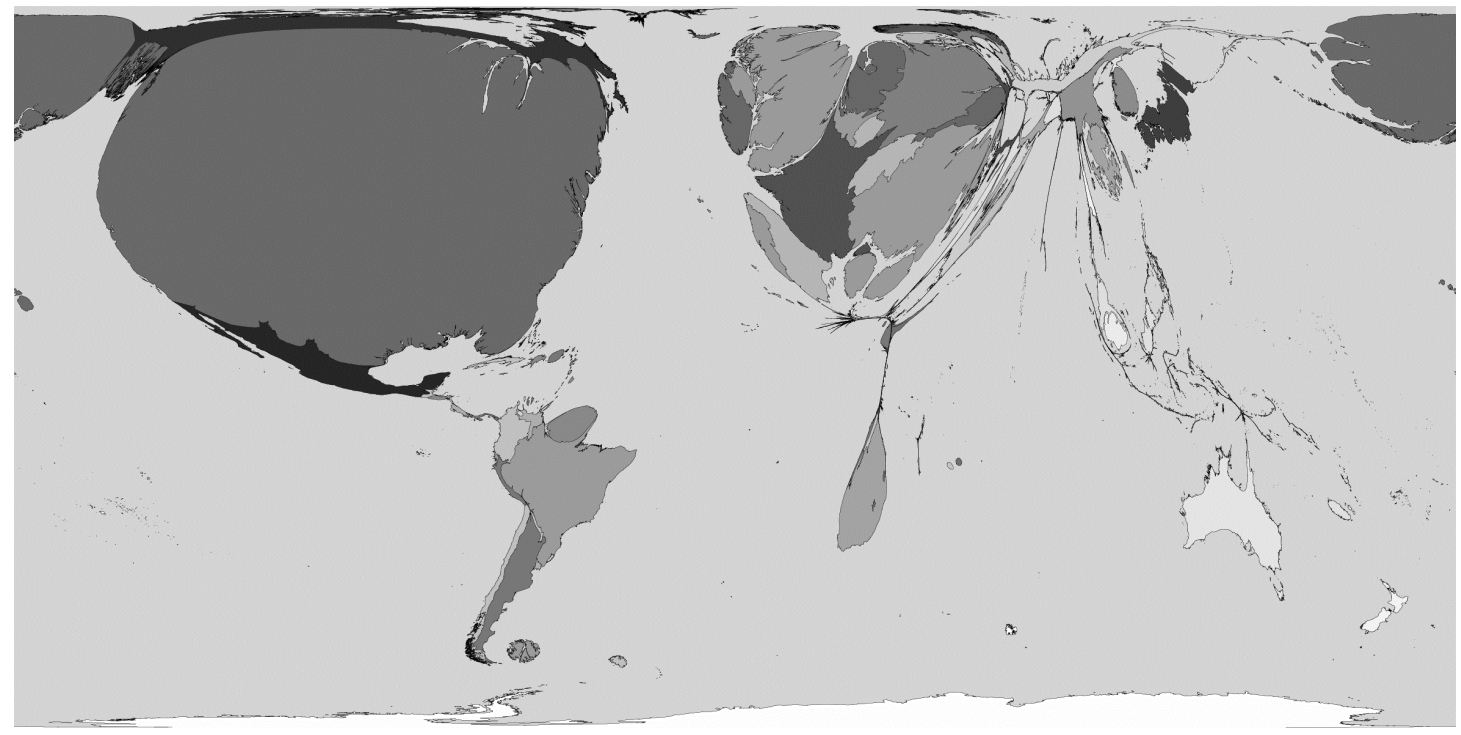

Source: Worldmapper map 158 (www.worldmapper.org)

\section{References:}


1 D. Dorling, J. Rigby, B. Wheeler., D. Ballas, B. Thomas, E. Fahmy, D. Gordon and R. Lupton (2007) Poverty, wealth and place in Britain, 1968 to 2005, Policy Press, Bristol (free pdf copies available from: http://www.jrf.org.uk/bookshop/eBooks/2019poverty-wealth-place.pdf)

${ }^{2}$ The Smiths (1984), Suffer Little Children

${ }^{3}$ F. Engels (1845) [on-line version], Conditions of the Working Class in England [on-line document], Marx/Engels Internet Archive (www.marxists.org), Available from: http://www.marxists.org/archive/marx/works/1845/conditionworking-class/index.htm

${ }^{4}$ S. Szreter, G. Mooney (1998) Urbanization, mortality, and the standard of living debate: new estimates of the expectation of life at birth in nineteenth-century British cities, Economic History Review, vol. 51, no. 1, pp. 84-112. (p.88)

${ }^{5}$ ibid, page 90

${ }^{6}$ G. Newman (1906) Infant mortality: a social problem, London: Methuen and co. (pp.168-169)

${ }^{7}$ D. Dorling, D. Ballas, B. Thomas, J. Pritchard, J. (2004) Pilot Mapping of Local Social Polarisation in Three Areas of England, 1971-2001, New Horizons project report to the Office for the Deputy Prime Minister, available on-line from: http://www.sasi.group.shef.ac.uk/research/pilot_mapping.htm

${ }^{8}$ P. Rees, D, Martin, D, P. Williamson (2002) (ed), The Census Data System, Wiley, Chichester

${ }^{9}$ D. Ballas (2014) What is small area estimation?, presentation given at the $6^{\text {th }}$ ESRC Research Methods Festival, St Catherine's College, University of Oxford, 8-10 July, UK National Centre for Research Methods (NCRM), available online: https://www.youtube.com/watch?v=g0187SuRSWg

${ }^{10}$ B. Thomas, D. Dorling (2004), Know Your Place: Housing wealth and inequality in Great Britain 1980-2003 and beyond, Shelter Policy Library (Electronic copies available on-line from: http://www.sheffield.ac.uk/sasi/publications/reports/knowyourplace.htm )

${ }^{11}$ D. Dorling, J. Rigby, B. Wheeler, D. Ballas. B. Thomas, E. Fahmy, D. Gordon, R. Lupton (2007) Poverty, wealth and place in Britain, 1968 to 2005, Policy Press, Bristol (free pdf copies available from: http://www.jrf.org.uk/bookshop/eBooks/2019poverty-wealth-place.pdf)

${ }^{12}$ D. Dorling, B. Thomas (2011), Bankrupt Britain: an atlas of social change, Policy Press, Bristol.

${ }^{13}$ D. Dorling (2005) A Human Geography of the UK, London: Sage.

${ }^{14}$ B. Thomas, D. Dorling (2007), Identity in Britain: A cradle-to-grave atlas, Policy Press, Bristol

${ }^{15}$ B.D. Hennig (2013) Rediscovering the world: Map transformations of human and physical space. Heidelberg / New York / Dordrecht / London (Springer)

${ }^{16}$ D. Ballas, D. Dorling, B. Hennig, B (2014), The Social Atlas of Europe, Policy Press, Bristol.

${ }^{17}$ D. Dorling, J. Rigby, B. Wheeler, D. Ballas, B. Thomas, E. Fahmy,,D. Gordon, D.,R. Lupton, R. (2007) Poverty, wealth and place in Britain, 1968 to 2005, Policy Press, Bristol (free pdf copies available from: http://www.jrf.org.uk/bookshop/eBooks/2019-poverty-wealthplace.pdf) 
${ }^{18}$ D. Gordon, C. Pantazis, C. (1997) Measuring Poverty: Breadline Britain in the 1990s, in David Gordon and Christina Pantazis (Eds.), Breadline Britain in the 1990s, Ashgate, Aldershot, pp. 1-47

${ }^{19}$ D. Dorling, J. Rigby, B. Wheeler, D. Ballas, B. Thomas, E. Fahmy, D. Gordon, D., R. Lupton (2007) Poverty, wealth and place in Britain, 1968 to 2005, Policy Press, Bristol (free pdf copies available from: http://www.jrf.org.uk/bookshop/eBooks/2019poverty-wealth-place.pdf)

${ }^{20}$ P. Townsend, (1979) Poverty in the United Kingdom, London, Allen Lane and Penguin Books, also freely available on-line from: http://www.poverty.ac.uk/free-resourcesbooks/poverty-united-kingdom (last accessed 17 April 2016).

${ }^{21}$ P. Toynbee (2006) 'Downsizing dreams', The Guardian, 8 April (http://books.guardian.co.uk/ review/story/0,,1749089,00.html, 23/08/2006).

${ }^{22}$ D. Dorling, J. Rigby, B. Wheeler, D. Ballas, B. Thomas, E. Fahmy, D. Gordon, R. Lupton (2007) Poverty, wealth and place in Britain, 1968 to 2005, Policy Press, Bristol (free pdf copies available from: http://www.jrf.org.uk/bookshop/eBooks/2019-poverty-wealth-place.pdf)

${ }^{23}$ Ibid

${ }^{24}$ Bradshaw, J, Finch, N (2003) 'Overlaps in Dimensions of Poverty', Journal of Social Policy, Vol. 32, no 4,pp. 513-525.

${ }^{25}$ A. Smith (1759), The theory of the moral sentiments, Reprint. Indianapolis: Liberty Classics, 1952. (p. 383)

${ }^{26}$ Ibid.

${ }^{27}$ B.S. Rowntree (2000) Poverty: a study of Town Life, centenary edition, Policy Press, Bristol

${ }^{28}$ C. Kenney (2005) Why Are We Worried About Income? Nearly Everything that Matters is Converging, World Development Vol. 33, No. 1, pp. 1-19.

${ }^{29}$ Ibid

${ }^{30}$ Ibid

${ }^{31}$ D. Ballas, D. Dorling, T. Nakaya, H. Tunstall, K. Hanaoka, T., Hanibuchi (2016), Happiness, social cohesion and income inequalities in Britain and Japan, in Tachibanaki, T (ed.), Advances in Happiness Research, Springer, pp. 119-138.

${ }^{32}$ A. Maddison (2007) The Contours of the World Economy 1-2030 AD, Oxford University Press, Oxford

${ }^{33}$ M. Poppins (1964) ... can you quote a fictitious person?

${ }^{34}$ D. Dorling (2006) Inequalities in Britain 1997-2006: the Dream that Turned Pearshaped, Local Economy, vol. 21, no 4, pp. 353-361.

${ }^{35}$ D. Boffey, (2015) How 30 years of a polarized economy have squeezed out the middle class, The Guardian, March $7^{\text {th }}$, http://www.theguardian.com/society/2015/mar/07/vanishing-middle-class-londoneconomy-divide-rich-poor-england

${ }^{36}$ D. Dorling (2006) Inequalities in Britain 1997-2006: the Dream that Turned Pearshaped, Local Economy, vol. 21, no 4, pp. 353-361. 